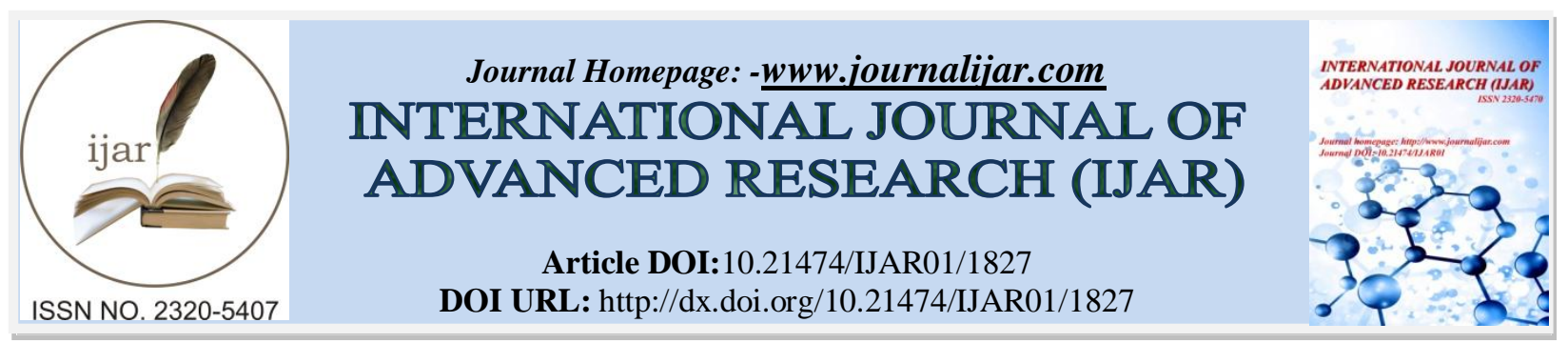

RESEARCH ARTICLE

\title{
DETECTION OF MUTANT DNA REPAIR GENE (OGG1) POLYMORPHISM IN SOME IRAQI PATIENTS TYPE1 DIABETES MELLITUS.
}

\author{
Bushra F. Hassan ${ }^{1}$, Najwa Sh. Ahmed ${ }^{2}$, Baydaa Ahmed Abed ${ }^{3}$ and Sarah Sameer ${ }^{1}$. \\ 1. Chemistry Department, College of Sciences for women, University of Baghdad. \\ 2. Biotechnology Research Center, Al-Nahrain University. \\ 3. National Diabetes Center Al-Mustansiria University.
}

\section{Manuscript Info}

Manuscript History

Received: 16 August 2016

Final Accepted: 13 September 2016

Published: October 2016

Key words:-

OGG1, Ser326Cys gene

polymorphism,Type1 diabetes.

\section{Abstract}

Background: Hyperglycemia and free fatty acid consumption are among the reasons for formation the oxidative stress. It may not be unexpected that diabetic subjects tend to have extra oxidative cell and reactive oxygen species (ROS) generation than healthy subjects. So the accumulation of reactive oxygen species (ROS) may generate extra damage to various biological macromolecules, counting DNA.

The study aimed to compare the genetic distribution of polymorphism genotype (OGG1) in Type1 diabetes with a number of healthy people.

Methods: The study involved a total (60) subjects including (30) people are suffering from diabetes Typeland (30) non-diabetic controls. All samples were taken from the Diabetes Center of the University of Al-Mustansiriya.

Results: The result showed all samples (patients and controls) bands when analyzed by the wizard genomic DNA purification Kit (Intron, Korea), also the result revealed that the amplified DNA products band of OGG1 gene at level $207 \mathrm{bp}$ in controls and in some patients.

Conclusion: our studies showed the OGG1 gene polymorphism appeared intype1 diabetes which may lead to many complications in diabetes patients that would be appeared in the future.

Copy Right, IJAR, 2016,. All rights reserved.

\section{Introduction:-}

Diabetes is a metabolic disorder disease characterized by hyperglycemia resulting from defects in insulin secretion, insulin action or both. In either case, the result is that glucose does not enter the cells and builds up in the blood. The chronic hyperglycemia of diabetes is linked with long term damage, dysfunction and failure of different organ, especially the heart, blood vessels kidney, nerves, and eyes. Also the longer duration of diabetes is the most risk of complications which rise significantly following teens. ${ }^{(1)(2)}$

Genomic DNA is susceptible to attack by ROS while at the same stage multiple DNA repair enzymes protect DNA against such oxidative damage. ${ }^{(3)}$ The major DNA repair pathways are nucleotide excision repair and base excision repair (BER) that can aid in reducing the level of 8-OHdG.8-oxoguanine DNA glycosylase 1 (OGG1) is a crucial enzyme of the BER pathway and catalyzes the removal of 8-OHdGreactive oxygen species (ROS) play role an increased in glucose levels that regulate by 8 -oxoguanosine DNA glycosylase (OGG1). ${ }^{(4)}{ }^{(5)}$ The OGG1 gene has

Corresponding Author:-Bushra F. Hassan1.

Address:-Chemistry Department, College of Sciences for women, University of Baghdad. 
been confirmed to contribute in the process of DNA repair. Furthermore, many researchers have observed that the expression of OGG1 is affected by the Ser326Cys polymorphism in the OGG1 gene. ${ }^{(6)(7)}$

\section{Methods:-}

DNA isolation and determination of OGG1 genotype:-

DNA was extracted from the whole blood by wizard genomic (DNA purification kit, Intron) according to the isolating genomic DNA from $200 \mu \mathrm{l}$ whole blood in each case. The volume of the extracted DNA solution was usually $100 \mu \mathrm{l}$ were stored at $-20^{\circ} \mathrm{C}$, and use the serial replication and the varying lengths of cutting restricted DNA to investigate the genetic diversity of the gene OGG1 of all members of this study.

A fragment 207 bp containing the Ser326Cys Polymorphism, which amplify the exon 7 region in which the Ser326Cys fragment is located. PCR amplification products were obtained using $25 \mu$ reactions (Template DNA 1.5 $\mu \mathrm{l}$, Primer Forward $0.8 \mu \mathrm{l} \mathrm{F}$, Primer Reverses $0.8 \mu \mathrm{l}$ R, Deionized Water $16.9 \mu \mathrm{l}$, PCR Master Mix $5 \mu \mathrm{l}$ ).Thermal cycling conditions for the OGG1 were: an initial denaturation step for 2 min at $94^{\circ} \mathrm{C}, 33$ cycles of denaturation for $30 \mathrm{~s}$ at $94^{\circ} \mathrm{C}$, primer annealing for $30 \mathrm{~s}$ at $61^{\circ} \mathrm{C}$, and primer extension for $30 \mathrm{~s}$ at $72^{\circ} \mathrm{C}$, followed by a final extension step for $10 \mathrm{~min}$ at $72^{\circ} \mathrm{C}$. The primers used for amplification of OGG1 gene exon 7, including Ser326Cys, were 5'ACT GTC ACT AGT CTC ACC AG-3' forward, and 5'-TGA ATT CGG AAG GTG CTTGGG GAA T-3' reverse.

\section{Results\&Discussion:-}

The wizard genomic DNA purification Kit (Intron, Korea) is used to DNA isolation from the whole blood cells in a short time for patients and healthy controls. All samples (patients and controls) showed bands, which indicated the genomic DNA on Agarose Gel Electrophoresis as shown in (Figure 1).

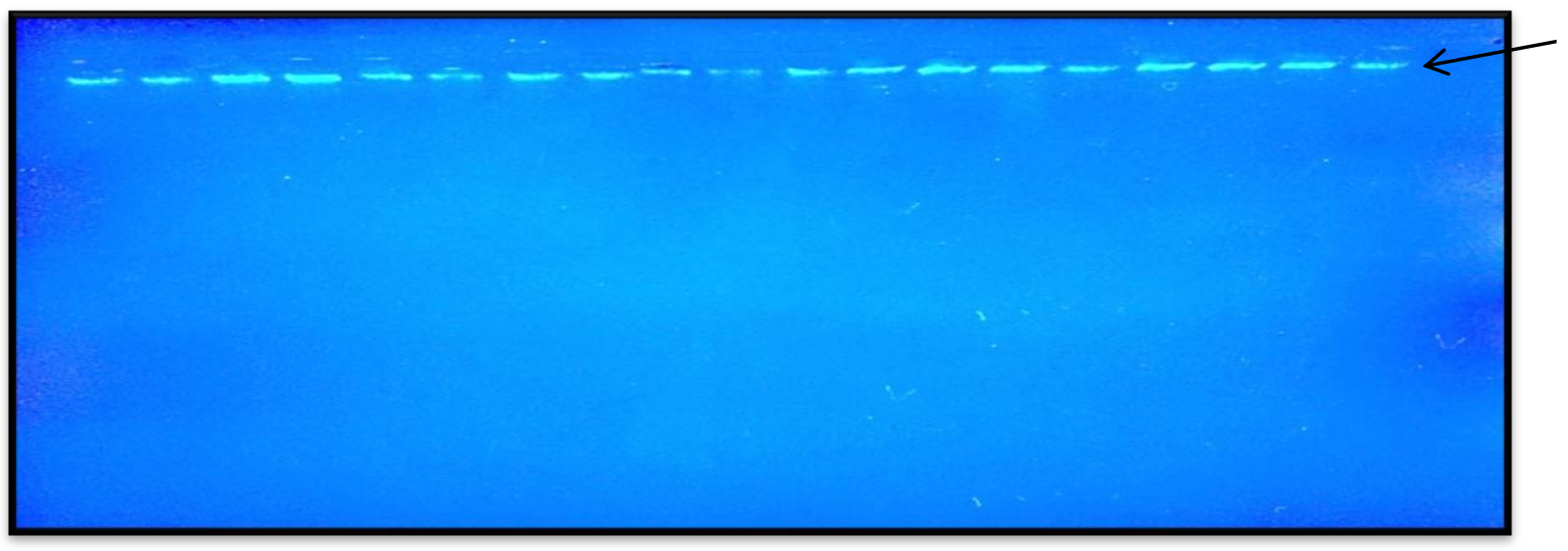

Figure 1:-Agarose gel electrophoresis of the genomic DNA samples (total DNA). Fragments were fractionated by electrophoresis on $1 \%$ agarose[60min/65v/55AMP], TBE $1 \mathrm{X}$ (tri-borate buffer) and visualized by Red stain.

The nucleic acid concentration and purity ratio were automatic calculated by Nano Drop software and the results were as follows (1.8- 2) $\mathrm{ng} / \mu \mathrm{l}$.

OGG1 gene was amplified in (60) samples (30 patients and 30 controls). Agarose gel electrophoresis of amplified DNA products showed the band of OGG1 gene at level 207 bp at (Figure 2). 




Figure 2:- A representive PCR analysis of OGG1 polymorphism. OGG1 genes PCR product resolved by (2\%) agarose gel electrophoresis $(1.5 \mathrm{hr} / 70 \mathrm{v})$. Amplified DNA in a $207 \mathrm{bp}$ fragment, Lane M, DNA molecular weight marker. Lane (1-6), negative control. Lane (7-16) is samples.

\section{Conclusion:-}

The current study revealed that the OGG1 gene exon 7 rejoin region in which the Ser326Cys fragment is located in 207 bp.

\section{References:-}

1. American Diabetes Association, (2014) Diagnosis and Classification of Diabetes Mellitus.Diabetes Care. 37 no. Supplement 1.S81-S90.

2. Nicolos J. Diabetes Mellitus, In RechardE,Behrman R, Robert M, Kliegman R., Nelson; (2006). Essential of pediatrics, 5 th ed. Philadelphia PA. Saunders; Ch170: 771-9.

3. Wiseman $H$ and Halliwell B. (1997). Damage to DNA by reactive oxygen and nitrogen species: role in inflammatory disease and progression to cancer. Biochem J 1996; 313: 17-29.

4. Michael Andrew McLean Florida International University, (2014). The relationship among serum levels of manganese superoxide dismutase and mtDNA 8-hydroxy-2'- deoxyguanosine, and dietary antioxidants intake in Type 2 Diabetes. Theses and Dissertations. Paper 1573. Page (8).

5. Croteau DL and Bohr VA. (1997). Repair of oxidative damage to nuclear and mitochondrial DNA in mammalian cells. J BiolChem 272:25409-25412.

6. Bruner SD, Norman DP and Verdine GL. (2000).Structural basis for recognition and repair of the endogenous mutagen 8-oxoguanine in DNA. Nature 403: 859-866.

7. Zhi-Yong Wu 1,2, Meng-Hong Wang 3 , Hong-Mei Qi 3 , Mei-Hua Wu 4 , Yu-ZhiGe 4 , Hua-Tai Li 4.(2015).Relationship between hOGG1 Ser326Cys gene polymorphism and coronary artery lesions in patients with diabetes mellitus. Int J ClinExp Med 8(10):18629-18637 www.ijcem.com /ISSN:1940-5901/ 